\title{
Enhancement of Cellulose Degradation Potential of Bacillus sp. Hcb-21 through Mutagenesis
}

\author{
Bhatia RK ${ }^{\star}$, Kumar R, Rathour RK, Kumar V, Sharma V, Rana N, Thakur S and Bhatt AK
}

Department of Biotechnology, Himachal Pradesh University, Summer Hill, Shimla, India

\begin{abstract}
Mutagenesis is a cost economic process generally preferred to produce some specific changes in the genetic makeup of organisms aiming to produce the desired protein/enzymes. Enzymes can be achieved to specific features like selectivity, stability, better substrate and product tolerance and better performance under harsh conditions with mutagenesis. Cellulase producing bacterial strain Bacillus sp. HCB-21 isolated from the forest soil of Himachal Pradesh showed highest cellulolytic activity, i.e., $8.56 \pm 0.32 \mathrm{U} / \mathrm{mg}$ protein. Different physiochemical parameters were optimized which resulted in 1.7 fold increase in cellulolytic activity. Further, mutants of Bacillus sp. HCB-21 were generated using physical and chemical mutagens for increased activity, stability and higher substrate/product tolerance of its cellulase enzyme. Mutant E-11 showed better cellulolytic potential besides enhanced tolerance to substrate concentration with 10 folds increase in overall enzymatic activity i.e. $85.04 \pm 0.46 \mathrm{U} / \mathrm{mg}$ protein in comparison to wild. This highly active and stable mutant can be used in various industrial applications to produce the valuable products.
\end{abstract}

Keywords: Enzyme; Mutagenesis; Cellulose degradation; Microorganism

\section{Introduction}

Cellulases refer to a group of enzymes which act together to hydrolyze cellulose into soluble sugars. These are distributed throughout the biological system such as plants, animals, and microorganisms. Microorganisms are considered to be the best source for cellulases $[1,2]$. Microbial cellulases are the most economic sources due to their easy availability higher growth rate and capability to grow on various inexpensive raw materials such as agriculture waste, forestry, and byproducts of food industries [3].

Despite the enormous advantages of enzyme-catalyzed processes, there are many biotechnological challenges in this field including the availability of novel producer strains, improvement of the catalytic efficiency of available strains and enzymes for increased activity and yield. To counter this problem mutagenesis is one of the most suited to enhance cellulase activity and its tolerance towards substrate/product. Earlier studies have also shown that mutagenesis can be applied to improve activity and stability of enzymes [4,5]. The combination of mutagenesis, directed evolution, and rational design offers great promise to accelerate the development of biocatalysts for applications in various industries like pharmaceutical, chemical, biofuel, and food industries [6]. In the present investigation, cellulolytic bacterial strain Bacillus sp. HCB-21 isolated from the soil of Himalayan pine forests was subjected to mutagenesis using ethyl methane sulphonate (EMS), methyl methane sulphonate (MMS), ethyl nitroso urea (ENU), methyl nitroso urea (MNU), 5-bromouracil and UV to enhance its cellulolytic potential and tolerance towards substrate/product. This mutant can be used to degrade the cellulose component of various natural waste biomasses into simple fermentable sugar moieties which further can be fermented to biofuel i.e. ethanol. This can be used in vehicles either in its pure form or used as a gasoline additive to reduce the emission of greenhouse gases.

\section{Materials and Methods}

\section{Chemicals}

All the chemicals were purchased from Lancaster Synthesis, England and mutagens namely EMS, MMS, ENU, MMU, 5-bromouracil from Sigma, USA and media components from Hi-Media, India. All other chemicals were of analytical grade.

\section{Microorganism}

Cellulase producing Bacillus sp. HCB-21 used in the present work was obtained from Research Lab-II, Department of Biotechnology, Himachal Pradesh University, Shimla. This strain was isolated from pine forest soil of Himachal Pradesh, identified at Institute of Microbial Technology (IMTECH) Chandigarh and characterized in our laboratory for its cellulolytic potential. The culture was maintained on nutrient agar plates and stored at $4^{\circ} \mathrm{C}$ until further use.

\section{Physiochemical parameters optimization}

In order to enhance the production of cellulase enzyme, different culture parameters were optimized for selected isolate Bacillus sp. HCB21. One variable at a time (OVAT) approach was adopted for optimization of culture conditions for the maximum production of cellulase enzyme. A number of variables such as eight media (M1-M8) M1 and M2 rich in carbon source, rest of six were mineral salt media and the carbon source, in these media was not clearly defined, incubation time (0-60 h), medium $\mathrm{pH}$ (4-11), inducer concentration $0.2-2 \%, \mathrm{pH}(4-11)$ and temperature $\left(10-50^{\circ} \mathrm{C}\right)$ were taken into consideration for assessing their effect on the production of cellulase enzyme.

*Corresponding author: Bhatia RK, Department of Biotechnology, Himachal Pradesh University, Summer Hill, Shimla, India; Tel: 0177-2831948; E-mail: arvind.bhatt@hpuniv.ac.in

Received September 19, 2017; Accepted October 27, 2017; Published October 31, 2017

Citation: Bhatia RK, Kumar R, Rathour RK, Kumar V, Sharma V, et al. (2017) Enhancement of Cellulose Degradation Potential of Bacillus sp. Hcb-21 through Mutagenesis. J Microb Biochem Technol 9: 257-265. doi: 10.4172/19485948.1000374

Copyright: @ 2017 Bhatia RK, et al. This is an open-access article distributed under the terms of the Creative Commons Attribution License, which permits unrestricted use, distribution, and reproduction in any medium, provided the original author and source are credited. 


\section{Mutant generation}

For the purpose of mutagenesis of Bacillus sp. HCB-21 was grown in medium M5 containing glycerol $10 \mathrm{~g}$, peptone $5 \mathrm{~g}$, malt extract $3 \mathrm{~g}$, yeast extract $3 \mathrm{~g} / \mathrm{L}$ and $0.4 \%(\mathrm{v} / \mathrm{v}) \mathrm{CMC}$ as inducer incubated at $30^{\circ} \mathrm{C}$ with continuous agitation at $150 \mathrm{rpm}$ up to its $\log$ phase $24 \mathrm{~h}$ [7]. Cells were harvested at $10,000 \mathrm{~g}$ for $5 \mathrm{~min}$, washed twice with sodium citrate buffer (0.1 M; pH 7.5) and cell pellet was suspended in $1 \mathrm{~mL}$ of the same buffer. These cells were further diluted up to $1 \mathrm{OD}$ at $600 \mathrm{~nm}$ and used for mutagenesis.

\section{$\mathrm{LD}_{50}$ calculation}

$\mathrm{LD}_{50}$ is that concentration of a mutagen where the number of survival cells remains half to that of initial. This was estimated by treating the resting cells of Bacillus sp. HCB-21 (1 OD at $600 \mathrm{~nm})$ with different concentrations of mutagens $\left(10-200 \mathrm{mg} \mathrm{mL}^{-1}\right)$. By counting the surviving colonies on agar plate after plating with appropriate dilution and comparing with control plate having untreated cells, $\mathrm{LD}_{50}$ of EMS, MMS, ENU, MNU and 5-bromouracil were calculated. For the generation of mutants, $1 \mathrm{ml}$ resting cells of Bacillus sp. HCB-21 (1 OD) were treated with different concentration of mutagen on the basis of $\mathrm{LD}_{50}$ calculation and incubated at $30^{\circ} \mathrm{C}$ for $2 \mathrm{~h}$. Treated resting cells were washed twice with $0.1 \mathrm{M}$ citrate buffer ( $\mathrm{pH} 7$ ), diluted with saline and then plated on CMC agar plate. After incubation at $30^{\circ} \mathrm{C}$ for $48 \mathrm{~h}$, the colonies of mutants were picked randomly and screened for cellulase activity towards CMC $[8,9]$.

\section{Mutants screening}

Different colonies of mutants were picked randomly and screened via same procedure discussed in previous section and cellulolytic activity was determined by cellulase assay for both wild and mutant strain. Stability of mutants was checked repeatedly up-to five subculturing.

\section{Comparative analysis of reaction conditions}

The various reaction conditions like buffer system, buffer $\mathrm{pH}(2$ $10)$, buffer strength (0.1-1 M), substrate concentration (0.5\%-5\%), enzyme concentration $(100 \mu \mathrm{L}-500 \mu \mathrm{L})$, reaction temperature $(30$ - $80^{\circ} \mathrm{C}$ ), reaction time (5-50 $\left.\mathrm{min}\right)$, for assay of cellulolytic activity of wild and mutant of Bacillus sp. HCB-21 were optimized for a comparative analysis and the cellulase enzyme assay was performed as per discussed earlier.

\section{Storage stability}

Storage stability of Bacillus sp. HCB-21 cellulase was evaluated by incubating the enzyme at different temperatures $\left(4^{\circ} \mathrm{C}, 30^{\circ} \mathrm{C}, 40^{\circ} \mathrm{C}\right.$, $50^{\circ} \mathrm{C}, 60^{\circ} \mathrm{C}$ ) for $10 \mathrm{~h}$ and samples were withdrawn after an interval of 1 $\mathrm{h}$ for their cellulase activity.

\section{Results}

The major objective of the present study was to enhance the cellulolytic potential of Bacillus sp. HCB-21 through mutagenesis. Optimization of different culture conditions, generation of hyperactive mutant, and comparative analysis of reaction parameters of wild and mutant have been presented in the following sections.

\section{Medium}

Growth medium plays a very important role in providing the desired enzymatic characters. Bacillus sp. HCB-21, when grown in eight different growth media (M1-M8) maximum cellulase activity recorded was $8.56 \pm 0.32 \mathrm{U} / \mathrm{mg}$ protein in medium M5 and the lowest activity was $1.12 \pm 0.24 \mathrm{U} / \mathrm{mg}$ protein in medium M3 (Figure 1). The growth Bacillus sp. HCB-21 was quite good in all growth media but cellulase activity was better only in M1 and M5. However, in media M2 and M3 the production of the non-specific crude enzyme was much higher but very little cellulolytic potential was recorded. Since medium M5 emerged as best, this growth medium was selected for future experiments.

\section{Incubation time}

The results depicted in Figure 2 showed that the production of cellulase enzyme by Bacillus sp. HCB-21 is related to its growth. Cellulolytic activity increased exponentially with increasing amount of protein production thereafter it showed a decline. The production of cellulase activity was maximum $(10.28 \pm 0.52 \mathrm{U} / \mathrm{mg}$ protein $)$ after 30

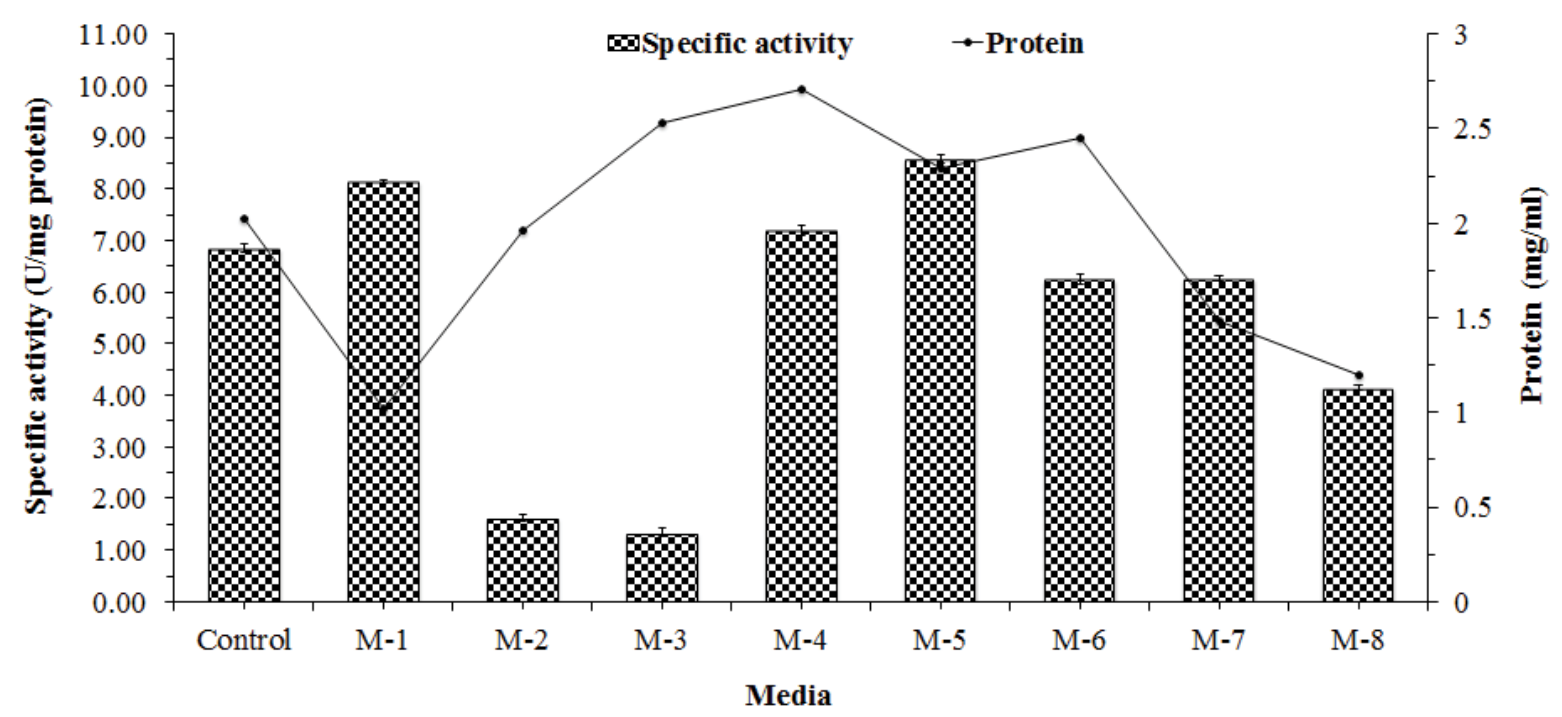

Figure 1: Effect of different media on the production of cellulase enzyme by Bacillus sp. HCB-21. 
$\mathrm{h}$ incubation and after that, a gradual decline was observed in cellulase activity as well as enzyme production (Figure 2).

\section{$\mathrm{P}^{\mathrm{H}}$ optimization}

$\mathrm{pH}$ of the growth medium induces morphological changes in the organism, alters its behavior and also affects the subsequent production of the enzyme. Bacillus sp. HCB-21 was grown in the selected growth medium having different $\mathrm{pH}$ ranging from $4-11$, in order to select the optimal $\mathrm{pH}$ for cellulase production (Figure 3) Maximum enzyme activity of $11.56 \pm 0.52 \mathrm{U} / \mathrm{mg}$ protein was observed at $\mathrm{pH} 8.0$ and least at $\mathrm{pH} 4(0.62 \pm 0.32 \mathrm{U} / \mathrm{mg}$ protein). The organism was quite active in a wider $\mathrm{pH}$ range of 6.5 to 9.5 with $1.82 \pm 0.46 \mathrm{U} / \mathrm{mg}$ proteins to 5.2 $\pm 0.53 \mathrm{U} / \mathrm{mg}$ protein yield of cellulase enzyme. The unique feature of this organism with good enzyme yield in wider $\mathrm{pH}$ range makes it interesting strain for industrial applications especially at high $\mathrm{pH}$ (Figure 3).

\section{Inducer concentration}

Cellulose (CMC) acts as an inducer for the production of cellulase. Cellulase production by Bacillus sp. HCB- 21 was studied by growing it in M5 medium ( $\mathrm{pH}-7$, temperature $30^{\circ} \mathrm{C}$ ) with varied $\mathrm{CMC}$ concentrations, 0.2 to $2.0 \%(\mathrm{w} / \mathrm{v})$ in the M5 medium and cellulase activity was recorded in each case. As shown in Figure 4, an increasing trend in the activity of cellulase was observed with CMC concentration up to $1.4 \%$ with maximum specific activity of $12.79 \pm 0.47 \mathrm{U} / \mathrm{mg}$, but thereafter, a decrease in activity was recorded with increasing CMC concentration. Interestingly substrate concentration of $0.8-1.60 \%$ had a very prominent effect on cellulase activity with a non-significant difference in enzyme yield but the concentration below and above this range showed a sharp decline in enzyme activity (Figure 4).

\section{Temperature}

To study the effect of varied levels of temperature on the production of cellulase by Bacillus sp. HCB-21, it was grown at different temperatures ranging from 10 to $50^{\circ} \mathrm{C}$ and the results have been summarized in
Figure 5. The results indicated that enzyme production decreased with increasing temperature with maximum enzyme activity of $14.51 \pm 0.63$ $\mathrm{U} / \mathrm{mg}$ proteins at $30^{\circ} \mathrm{C}$. Further increase in temperature upto $50^{\circ} \mathrm{C}$ resulted in a decline in the cellulase activity with the minimum activity of $3.42 \pm 0.34 \mathrm{U} / \mathrm{mg}$ proteins at $50^{\circ} \mathrm{C}$ (Figure 5).

\section{Mutant generation}

Mutants of Bacillus sp. HCB-21 for enhanced cellulolytic activity and improving its tolerance towards higher product concentration were generated using different mutagens. LD50 of EMS, MMS, ENU, MNU and 5-bromouracil for Bacillus sp. HCB-21 were found to be 75, 75, 60,64 and $200 \mathrm{mg} \mathrm{mL}^{-1}$, respectively. Total 243 mutants generated with these mutagens and 19 mutants were found as positive for cellulose degradation (data not shown) of which five maximum cellulolytic activity were selected. Out of five only one mutant EMS-11 which retained its cellulase activity, (E-11) was selected for further studies.

\section{Mutant E-11 stability}

The stability of mutant E-11 was checked by repeated sub-culturing and determination of cellulase activity. The mutant E-11 exhibited maximum activity of $39.6 \pm 0.55 \mathrm{U} / \mathrm{mg}$ proteins in comparison to wild $14.51 \pm 0.45 \mathrm{U} / \mathrm{mg}$ proteins. The stability profile of cellulase activity for mutant E-11 has been shown in Figure 6.

\section{Buffer system and $\mathrm{pH}$}

Five different buffer systems viz. Tris- $\mathrm{HCl}$, citrate, potassium phosphate, carbonate-bicarbonate and glycine $\mathrm{NaOH}$ and $(50 \mathrm{mM})$ with varying $\mathrm{pH}$ were tested for cellulase activity by the selected mutant E-11. Among these, the highest cellulase activity of $42.12 \pm 0.55 \mathrm{U} / \mathrm{mg}$ protein was exhibited by the mutant in citrate buffer $(50 \mathrm{mM})$ at $\mathrm{pH} 6.0$. The wild isolate also showed the highest activity in citrate buffer (14.96 $\pm 0.47 \mathrm{U} / \mathrm{mg}$ protein) at $\mathrm{pH} 6$ (Table 1 ). In case of other buffers both wild as well mutant did not show much improvement in the enzyme activity. It is quite evident from the results that this enzyme showed activity in acidic $\mathrm{pH}$ while buffers which are alkaline in nature did not

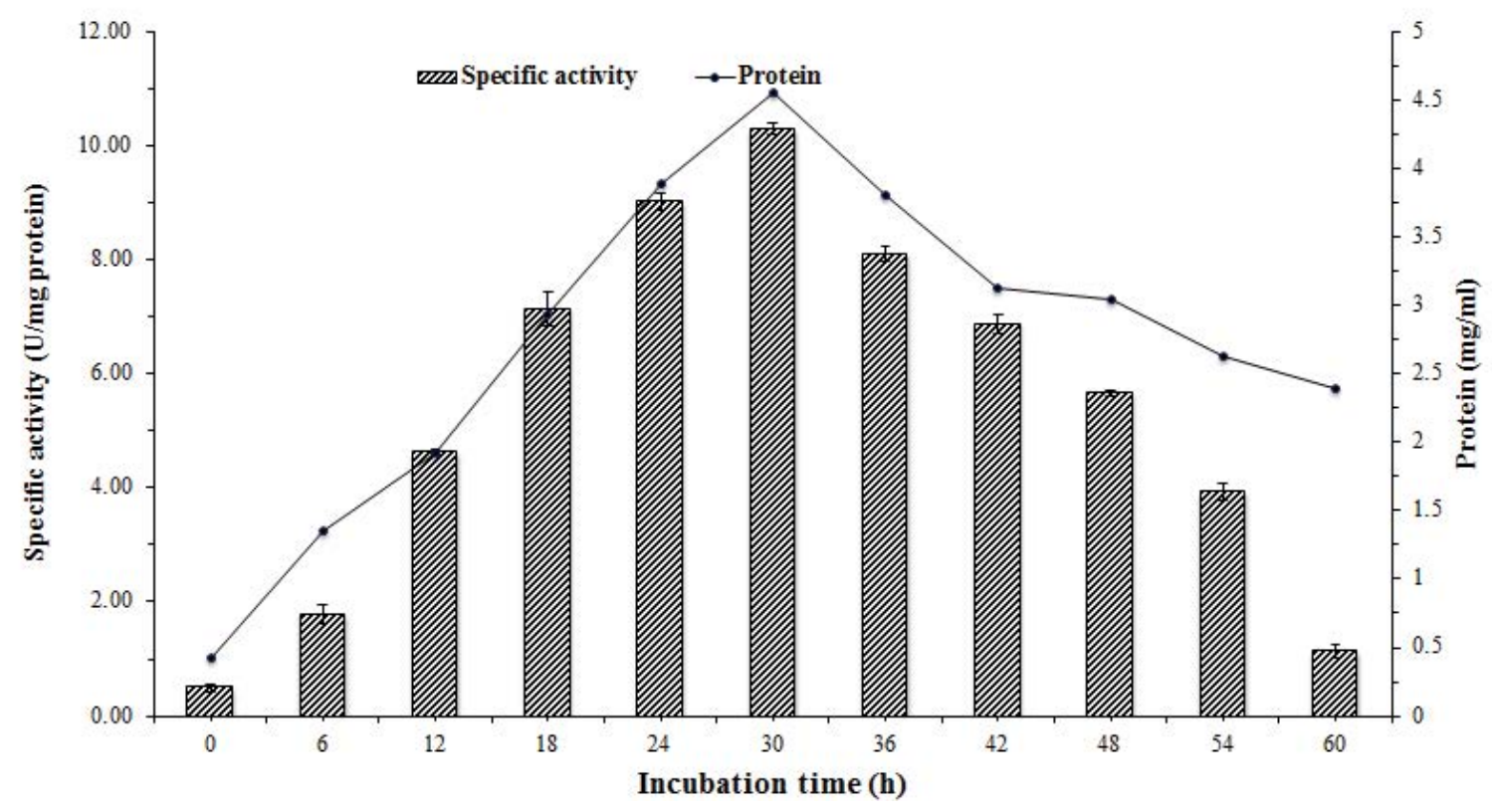

Figure 2: Effect of incubation time on the production of cellulase enzyme by Bacillus sp. HCB-21. 


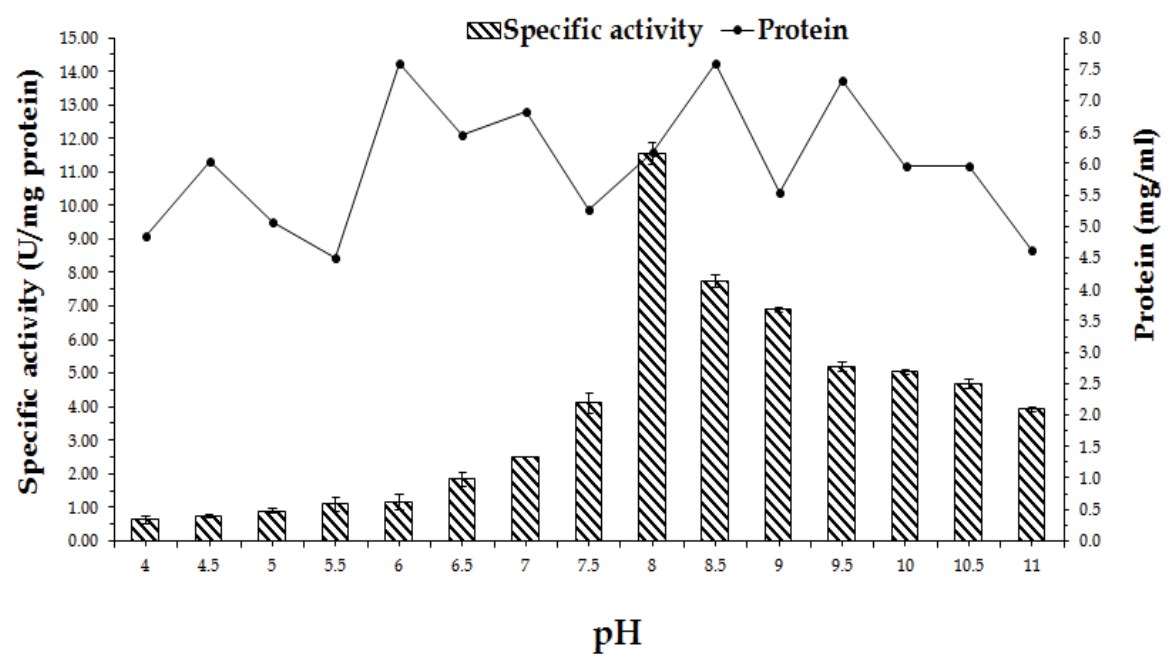

Figure 3: Effect of $\mathrm{pH}$ on cellulase activity and enzyme production by Bacillus sp. HCB-21.

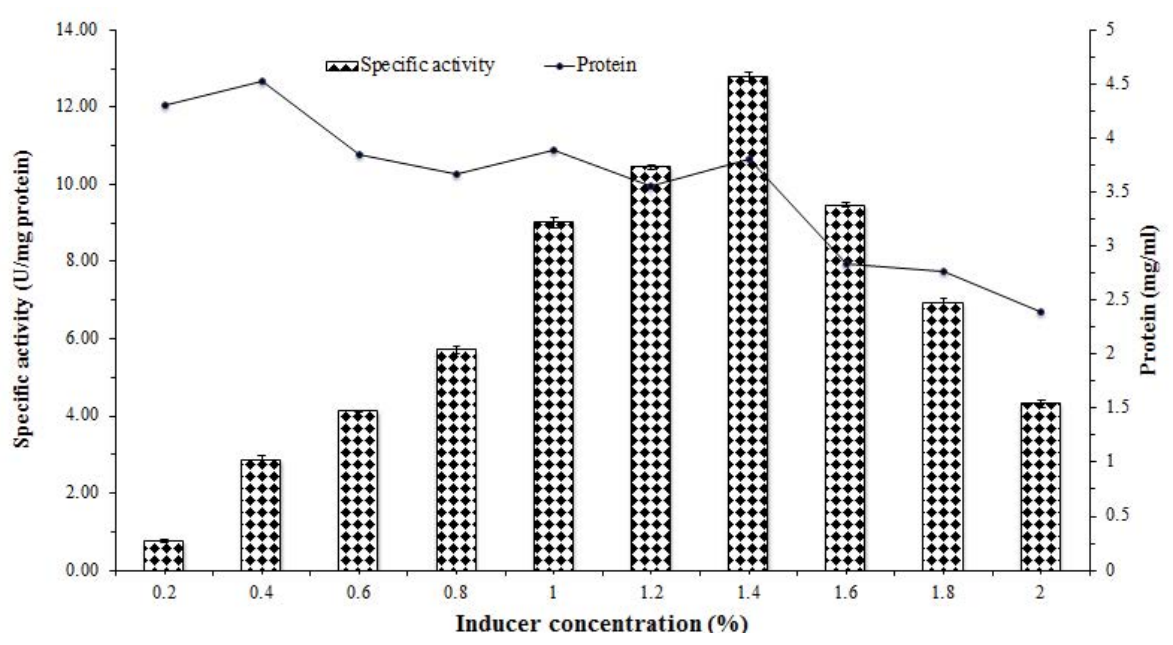

Figure 4: Effect of CMC concentration on cellulase activity and its production by Bacillus sp. HCB21.

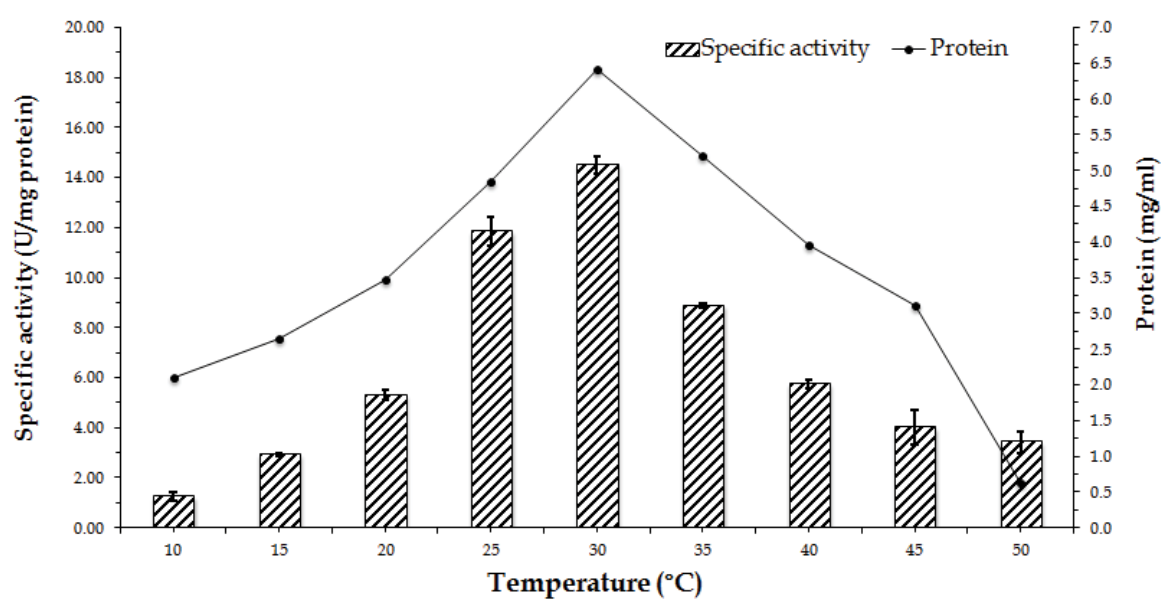

Figure 5: Effect of temperature on cellulase activity and its production by Bacillus sp. HCB21. 


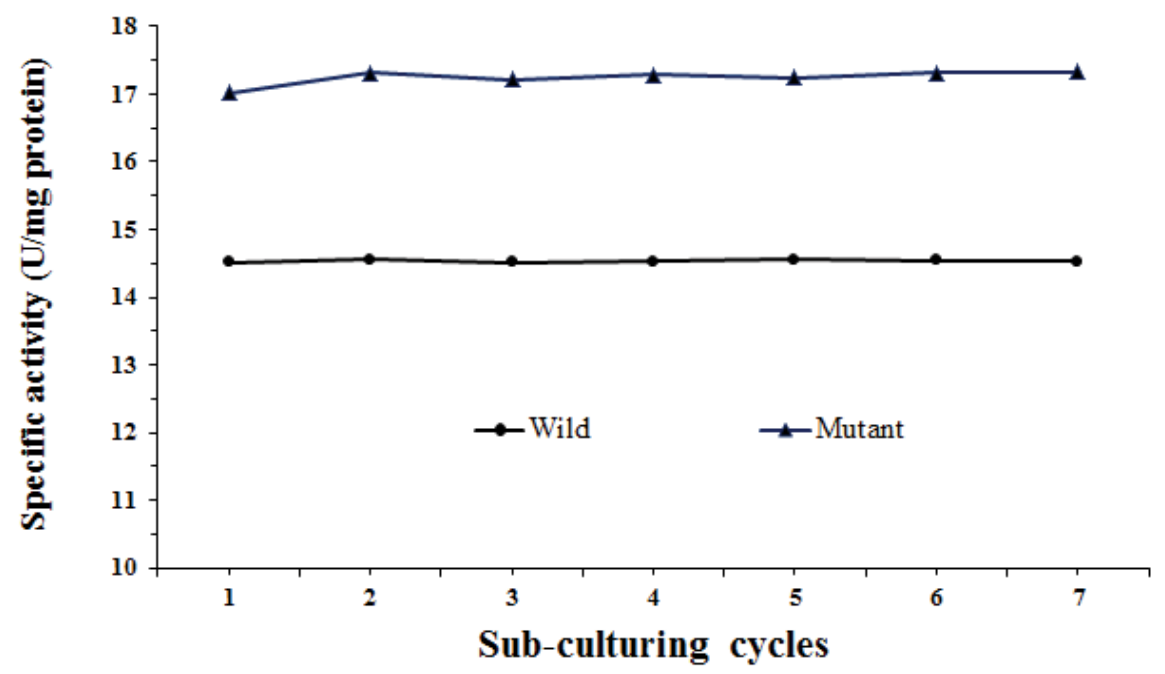

Figure 6: Stability profile of cellulase activity of mutant E-11 against wild strain.

Comparative analysis of reaction parameters for cellulase activity of the wild and mutant EMS-11 of Bacillus sp. HCB-21

\begin{tabular}{|c|c|c|c|c|c|c|c|c|c|c|}
\hline \multirow{3}{*}{$\begin{array}{c}\begin{array}{c}\text { pH/Buffer } \\
\text { System }\end{array} \\
\text { Strain }\end{array}$} & \multicolumn{10}{|c|}{ Specific activity (U/mg protein) } \\
\hline & \multicolumn{2}{|c|}{ Tris-HCI } & \multicolumn{2}{|c|}{ Citrate } & \multicolumn{2}{|c|}{ Potassium phosphate } & \multicolumn{2}{|c|}{ Carbonate-bicarbonate } & \multicolumn{2}{|c|}{ Glycine $\mathrm{NaOH}$} \\
\hline & Wild & Mutant E-11 & Wild & Mutant E-11 & Wild & Mutant E-11 & Wild & Mutant E-11 & Wild & Mutant E-11 \\
\hline 2 & $4.16 \pm 0.45$ & $10.24 \pm 0.12$ & & & & & & & & \\
\hline 2.5 & $5.24 \pm 0.31$ & $12.43 \pm 0.22$ & & & & & & & & \\
\hline 3 & $5.56 \pm 0.42$ & $13.96 \pm 0.32$ & $10.96 \pm 0.23$ & $14.96 \pm 0.46$ & & & & & & \\
\hline 3.5 & $6.06 \pm 0.23$ & $14.19 \pm 0.24$ & $10.96 \pm 0.35$ & $16.96 \pm 0.40$ & & & & & & \\
\hline 4 & $6.86 \pm 0.33$ & $14.23 \pm 0.54$ & $12.96 \pm 0.34$ & $24.96 \pm 0.24$ & & & & & & \\
\hline 4.5 & $7.25 \pm 0.15$ & $15.49 \pm 0.42$ & $13.96 \pm 0.46$ & $28.96 \pm 0.67$ & & & & & & \\
\hline 5 & $7.44 \pm 0.22$ & $16.56 \pm 0.32$ & $13.96 \pm 0.12$ & $34.96 \pm 0.56$ & & & & & & \\
\hline 5.5 & & & $14.96 \pm 0.54$ & $38.96 \pm 0.24$ & & & & & & \\
\hline 6 & & & $14.96 \pm 0.47$ & $42.12 \pm 0.55$ & $13.26 \pm 0.45$ & $34.97 \pm 0.43$ & & & & \\
\hline 6.5 & & & $13.96 \pm 0.33$ & $40.96 \pm 0.34$ & $14.34 \pm 0.34$ & $35.16 \pm 0.24$ & & & & \\
\hline 7 & & & $12.96 \pm 0.45$ & $40.96 \pm 0.14$ & $14.86 \pm 0.23$ & $38.44 \pm 0.54$ & & & $14.44 \pm 0.54$ & $34.54 \pm 0.24$ \\
\hline 7.5 & & & & & $12.29 \pm 0.54$ & $37.72 \pm 0.33$ & & & $14.86 \pm 0.21$ & $34.56 \pm 0.40$ \\
\hline 8 & & & & & $11.25 \pm 0.22$ & $35.35 \pm 0.24$ & $13.12 \pm 0.34$ & $33.88 \pm 0.16$ & $13.43 \pm 0.12$ & $24.78 \pm 0.34$ \\
\hline 8.5 & & & & & $11.45 \pm 0.24$ & $30.12 \pm 0.32$ & $12.45 \pm 0.28$ & $30.16 \pm 0.67$ & $13.65 \pm 0.32$ & $24.33 \pm 0.24$ \\
\hline 9 & & & & & $9.22 \pm 0.36$ & $28.08 \pm 0.38$ & $12.67 \pm 0.16$ & $27.34 \pm 0.25$ & $9.34 \pm 0.20$ & $14.87 \pm 0.15$ \\
\hline 9.5 & & & & & & & $11.36 \pm 0.17$ & $22.22 \pm 0.32$ & $7.89 \pm 0.14$ & $9.34 \pm 0.26$ \\
\hline 10 & & & & & & & $9.54 \pm 0.19$ & $14.78 \pm 0.24$ & $5.33 \pm 0.45$ & $7.12 \pm 0.21$ \\
\hline
\end{tabular}

Table 1: Showing comparative analysis of different buffers and their $\mathrm{pH}$ on cellulase activity of mutant $\mathrm{E}-11$ against the wild strain.

work efficiently and showed decreased trends of cellulose activity in alkaline $\mathrm{pH}$.

\section{Buffer ionic strength}

The molarity of citrate buffer of $\mathrm{pH} 6.0$ was varied from 0.1 to 1.0 $\mathrm{M}$ for the assay of cellulase activity. The wild strain showed maximum activity $16.02 \mathrm{U} / \mathrm{mg}$ protein in $0.5 \mathrm{M}$ citrate buffer while mutant showed highest activity at $0.6 \mathrm{M}$ of citrate buffer $(43.89 \pm 0.43 \mathrm{U} / \mathrm{mg}$ protein) at $\mathrm{pH} 6.0$ (Figure 7). The wild strain of Bacillus sp. HCB-21 also exhibited cellulase activity in the same buffer at same $\mathrm{pH}$ but at different concentration. On increasing the ionic strength of buffer, both the wild and mutant strains showed a decrease in enzyme activity which may be due to the instability of ES complex at higher buffer molarity.

\section{Substrate concentration}

Effect of substrate concentration on cellulase activity was studied using various concentrations ( $0.5 \%$ to $5 \%$ ) of CMC. Highest cellulase activity for wild strain was recorded with $1 \%$ CMC $(16.26 \pm 0.54 \mathrm{U} / \mathrm{mg}$ protein) while mutant showed the highest activity $(48.12 \pm 0.27 \mathrm{U} / \mathrm{mg}$ protein) at $1.5 \%$ concentration of substrate (Figure 8 ). Increasing CMC concentrations above $1.5 \%$ resulted in decreased cellulase activities. However, both the mutant and wild isolate did show comparatively high enzyme activity in a wider range (1-3\%) of substrate, i.e., CMC.

\section{Enzyme concentration}

Effect of enzyme concentration on cellulase activity was studied using varied enzyme volume volumes ranging from $100 \mu \mathrm{L}$ to $500 \mu \mathrm{L}$ and enzyme activity was recorded in each case (Figure 9). Highest cellulase activity for wild isolate was observed at $200 \mu \mathrm{L}(20.82 \pm$ $0.56 \mathrm{U} / \mathrm{mg}$ protein) while highest activity was recorded with $300 \mu \mathrm{L}$ of enzyme solution $(64.24 \pm 0.37 \mathrm{U} / \mathrm{mg}$ protein). Hence, it was found 


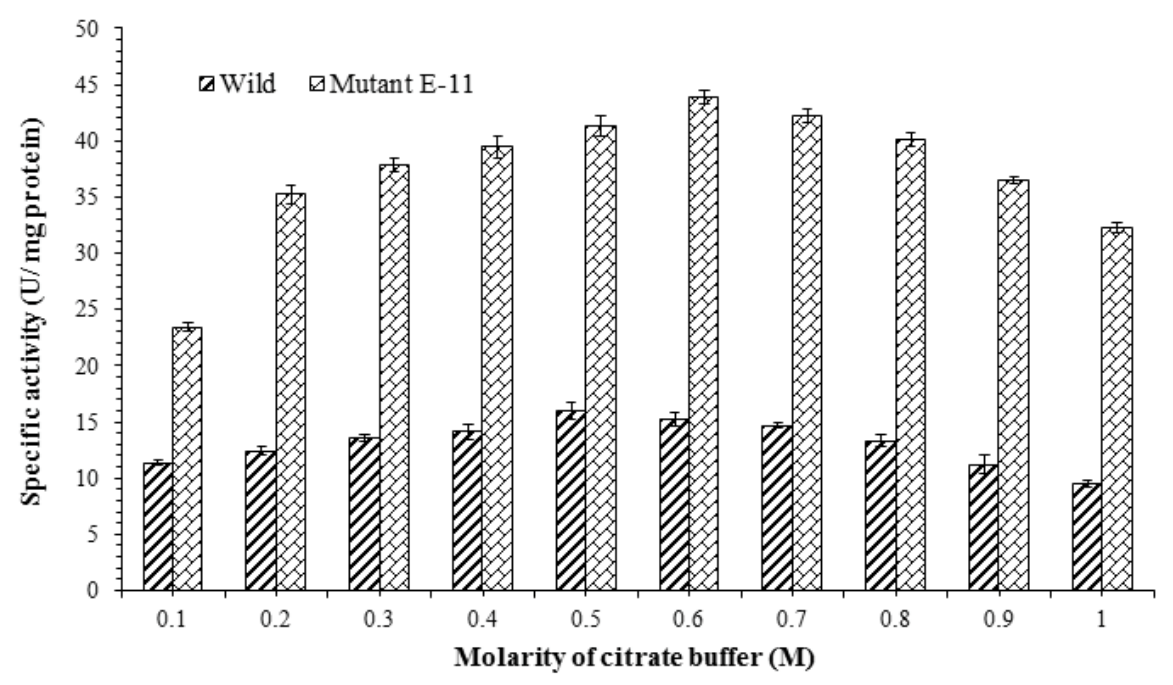

Figure 7: Effect of citrate buffer molarity on cellulase activity of wild strain Bacillus sp. HCB 21 and mutant E-11.

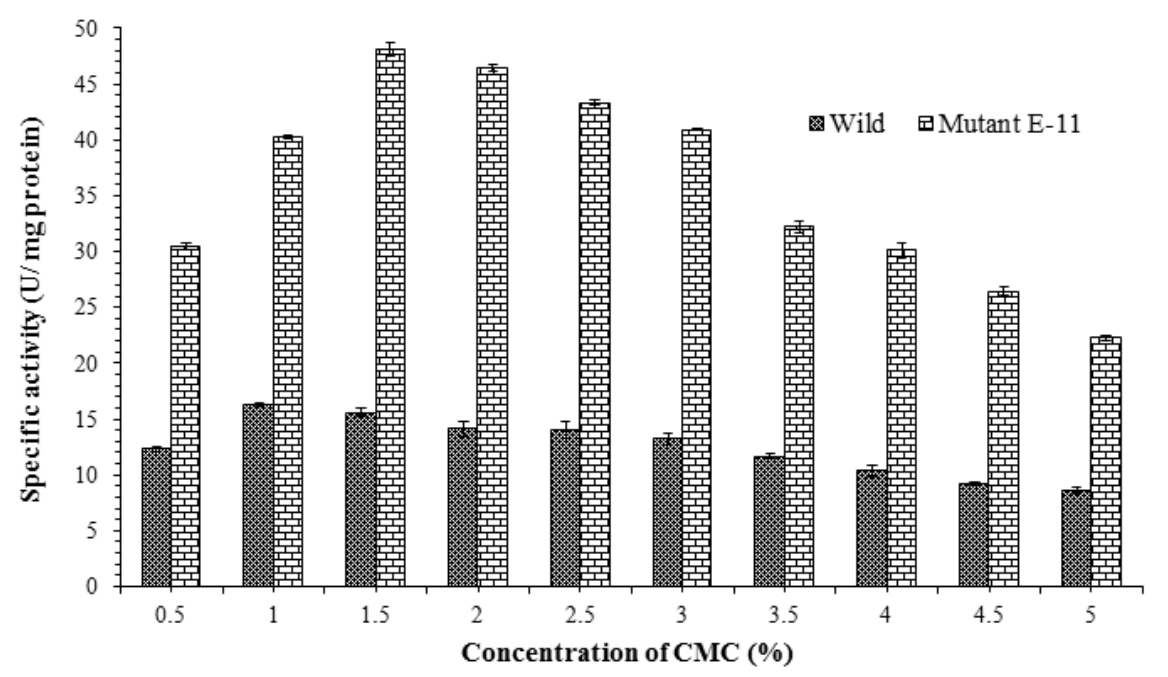

Figure 8: Comparative analysis of substrate concentration on cellulase activity of wild strain Bacillus sp. HCB 21 and mutant E-11.

that the mutant EMS-11 can tolerate more substrate concentration as compared to mild strain.

\section{Reaction temperature}

The cellulase activity of mutant E-11 was assayed at a wide temperature range $\left(30^{\circ} \mathrm{C}\right.$ to $\left.80^{\circ} \mathrm{C}\right)$ to see the comprehensive effect of varied level levels of temperature. Both wild and mutant strains exhibited maximum cellulase activity at $70^{\circ} \mathrm{C}$ with $20.87 \pm 0.56 \mathrm{U} / \mathrm{mg}$ protein and $76.45 \pm 0.22 \mathrm{U} / \mathrm{mg}$ protein respectively in $0.1 \mathrm{M}$ citrate buffer ( $\mathrm{pH}$ 6.0) (Figure 10). The cellulase from HCB-21 and its mutant E-11 seem thermotolerant when checked with reaction temperature $\left(30-70^{\circ} \mathrm{C}\right)$. An increase was observed in the cellulase activity of this strain up to $70^{\circ} \mathrm{C}$. However, a decline started beyond $70^{\circ} \mathrm{C}$ due to the instability of enzyme activity.

\section{Reaction time}

The cellulase assay was performed at selected temperatures for both wild and mutant strains. The samples were withdrawn at an interval of $5 \mathrm{~min}$ up to the period of $45 \mathrm{~min}$ and cellulase assay was done in each case. The highest activity was shown by wild isolate after at 25 minutes $22.13 \pm 0.28 \mathrm{U} / \mathrm{mg}$ protein and for mutant after $20 \mathrm{~min}$ with $85.04 \pm$ $0.46 \mathrm{U} / \mathrm{mg}$ protein that might be due to the faster interaction of mutant cellulase than wild cellulose (Figure 11).

\section{Shelf life}

The shelf life of cellulase enzyme from HCB-21 of wild and mutant E-11 was investigated by pre-incubating the enzyme at different temperatures, i.e., $30^{\circ} \mathrm{C}, 40^{\circ} \mathrm{C}, 50^{\circ} \mathrm{C}, 60^{\circ} \mathrm{C}, 70^{\circ} \mathrm{C}$ and $80^{\circ} \mathrm{C}$. The cellulase activity was checked after every $20 \mathrm{~min}$ and recorded the enzyme preparation were found stable at $30^{\circ} \mathrm{C}, 40^{\circ} \mathrm{C}$ till 3 hours but thereafter a decrease in activity was observed (Table 2). At $70^{\circ} \mathrm{C}$ and $80^{\circ} \mathrm{C}$, there was an abrupt decline in activity after $1 \mathrm{~h}$ of incubation at the respective temperatures. A similar trend was also observed for the mutant E-11. 


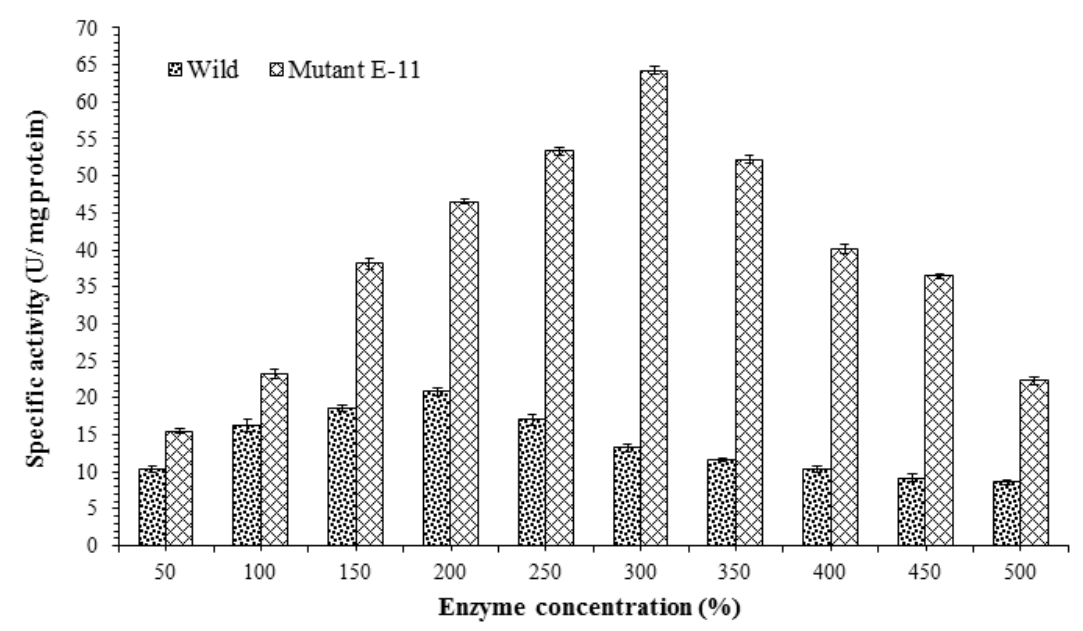

Figure 9: Effect of enzyme concentration on cellulase activity of wild strain Bacillus sp. HCB 21 and mutant E-11.

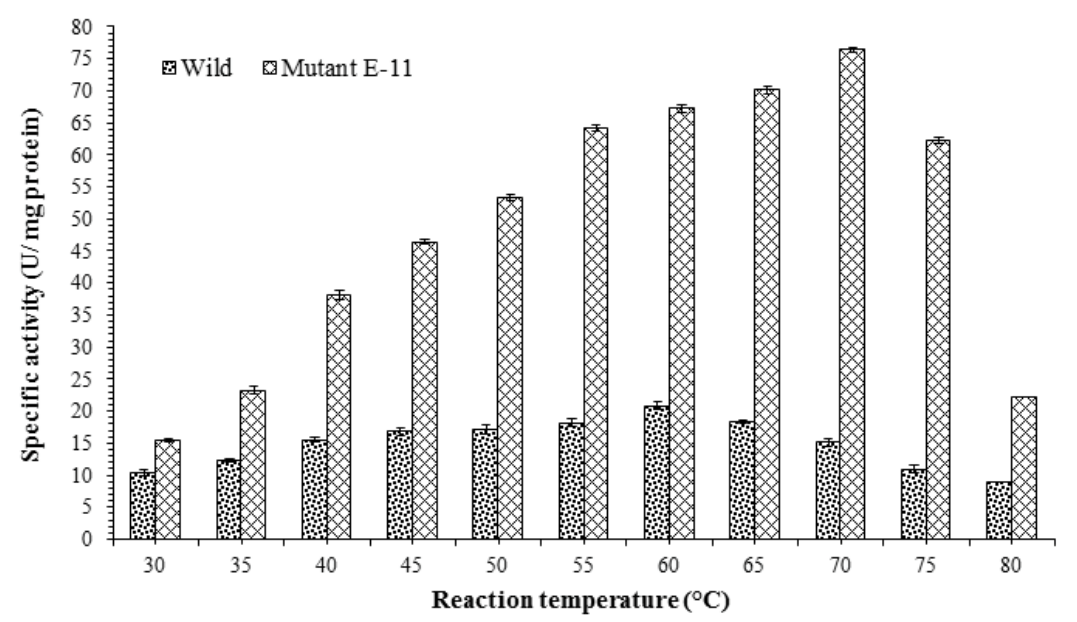

Figure 10: Comparative analysis of temperature on cellulase activity of wild strain Bacillus sp. HCB 21 and mutant E-11.

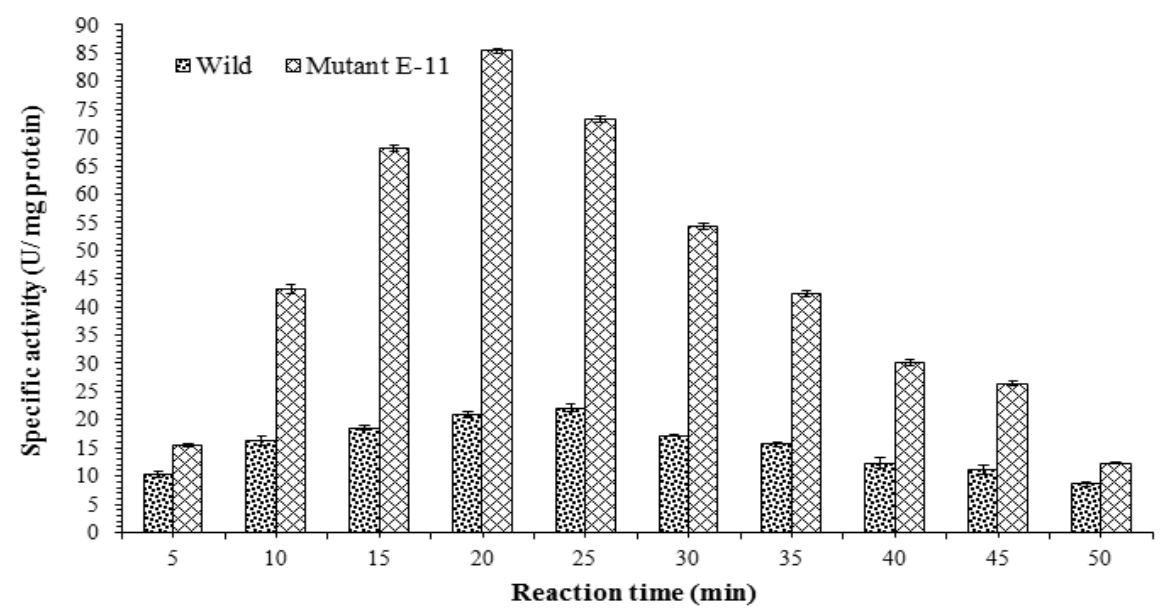

Figure 11: Effect of reaction time on cellulase activity of wild strain Bacillus sp. HCB-21 and mutant E-11. 
Citation: Bhatia RK, Kumar R, Rathour RK, Kumar V, Sharma V, et al. (2017) Enhancement of Cellulose Degradation Potential of Bacillus sp. Hcb-21 through Mutagenesis. J Microb Biochem Technol 9: 257-265. doi: 10.4172/1948-5948.1000374

\begin{tabular}{|c|c|c|c|c|c|c|c|c|c|}
\hline $\begin{array}{c}\text { Strain and } \\
\text { Temperature }\end{array}$ & $\begin{array}{c}20 \text { min } \\
\text { U/mg protein }\end{array}$ & $\begin{array}{c}40 \min \\
\mathrm{U} / \mathrm{mg} \text { protein }\end{array}$ & $\begin{array}{c}60 \text { min } \\
\text { U/mg protein }\end{array}$ & \begin{tabular}{|c|}
$80 \min \mathrm{U} /$ \\
$\mathrm{mg}$ protein
\end{tabular} & $\begin{array}{c}100 \text { min } \\
\mathrm{U} / \mathrm{mg} \text { protein }\end{array}$ & $\begin{array}{c}120 \text { min } \\
\mathrm{U} / \mathrm{mg} \text { protein }\end{array}$ & $\begin{array}{c}140 \text { min } \\
\mathrm{U} / \mathrm{mg} \text { protein }\end{array}$ & \begin{tabular}{c|}
$160 \mathrm{~min}$ \\
$\mathrm{U} / \mathrm{mg}$ protein
\end{tabular} & $\begin{array}{c}180 \text { min } \\
\mathrm{U} / \mathrm{mg} \text { protein }\end{array}$ \\
\hline Wild $\left(30^{\circ} \mathrm{C}\right)$ & $2.13 \pm 0.28$ & $22.43 \pm 0.23$ & $21.87 \pm 0.32$ & $21.21 \pm 0.31$ & $20.32 \pm 0.33$ & $20.21 \pm 0.54$ & $19.43 \pm 0.21$ & $19.54 \pm 0.23$ & $19.21 \pm 0.43$ \\
\hline Muta & $.04 \pm 0.46$ & $65 \pm 0.45$ & $40 \pm 0.28$ & $.60 \pm 0.33$ & $.63 \pm 0.65$ & $84.76 \pm 0.45$ & $83.78 \pm 0.79$ & $83.76 \pm 0.54$ & $83.54 \pm 0.65$ \\
\hline Wild $\left(40^{\circ} \mathrm{C}\right)$ & $.13 \pm 0.28$ & $1.87 \pm 0.76$ & $0.45 \pm 0.45$ & $0.66 \pm 0.64$ & $19.13 \pm 0.76$ & $19.20 \pm 0.28$ & $18.76 \pm 0.23$ & $18.32 \pm 0.26$ & $17.13 \pm 0.76$ \\
\hline Mutant $\left(40^{\circ} \mathrm{C}\right)$ & $85.04 \pm 0.46$ & $85.21 \pm 0.53$ & $84.32 \pm 0.90$ & $84.32 \pm 0.73$ & $84.18 \pm 0.23$ & $83.10 \pm 0.98$ & $83.23 \pm 0.43$ & $83.76 \pm 0.24$ & $82.43 \pm 0.76$ \\
\hline Wild $\left(50^{\circ} \mathrm{C}\right)$ & $22.13 \pm 0.28$ & $21.76 \pm 0.86$ & $20.75 \pm 0.32$ & $20.42 \pm 0.31$ & $19.11 \pm 0.77$ & $19.15 \pm 0.32$ & $18.65 \pm 0.87$ & $17.13 \pm 0.23$ & $17.76 \pm 0.23$ \\
\hline Mutant $\left(50^{\circ} \mathrm{C}\right)$ & $5.04 \pm 0.46$ & $84.52 \pm 0.40$ & $84.22 \pm 0.22$ & $83.70 \pm 0.33$ & $82.15 \pm 0.22$ & $82.31 \pm 0.42$ & $81.87 \pm 0.32$ & $81.18 \pm 0.88$ & $80.16 \pm 0.29$ \\
\hline Wild $\left(60^{\circ} \mathrm{C}\right)$ & $2.13 \pm 0.28$ & $20.46 \pm 0.24$ & $19.31 \pm 0.67$ & $19.61 \pm 0.26$ & $18.13 \pm 0.75$ & $18.76 \pm 0.87$ & $17.32 \pm 0.23$ & $17.32 \pm 0.42$ & $16.37 \pm 0.32$ \\
\hline Mutant $\left(60^{\circ} \mathrm{C}\right)$ & $85.04 \pm 0.46$ & $84.68 \pm 0.54$ & $83.86 \pm 0.68$ & $83.16 \pm 0.29$ & $82.53 \pm 0.23$ & $81.82 \pm 0.24$ & $80.42 \pm 0.90$ & $80.65 \pm 0.82$ & 0.87 \\
\hline Wild $\left(70^{\circ} \mathrm{C}\right)$ & $22.13 \pm 0.28$ & $19.79 \pm 0.79$ & $18.42 \pm 0.31$ & $17.72 \pm 0.13$ & $16.76 \pm 0.76$ & $15.32 \pm 0.27$ & $15.18 \pm 0.32$ & $14.13 \pm 0.76$ & $14.42 \pm 0.23$ \\
\hline Mutant $\left(70^{\circ} \mathrm{C}\right)$ & $85.04 \pm 0.46$ & $84.12 \pm 0.43$ & $83.32 \pm 0.54$ & $82.15 \pm 0.13$ & $81.74 \pm 0.22$ & $80.65 \pm 0.64$ & $79.11 \pm 0.66$ & $78.87 \pm 0.22$ & $77.48 \pm 0.75$ \\
\hline Wild $\left(80^{\circ} \mathrm{C}\right)$ & $22.13 \pm 0.28$ & $18.74 \pm 0.23$ & $16.70 \pm 0.76$ & $14.31 \pm 0.19$ & $13.28 \pm 0.21$ & $11.76 \pm 0.28$ & $09.76 \pm 0.22$ & $08.34 \pm 0.76$ & $07.24 \pm 0.63$ \\
\hline Mutant $\left(80^{\circ} \mathrm{C}\right)$ & $85.04 \pm 0.46$ & $83.86 \pm 0.65$ & $81.32 \pm 0.68$ & $80.97 \pm 0.43$ & $78.65 \pm 0.75$ & $76.76 \pm 0.67$ & $74.87 \pm 0.95$ & $72.76 \pm 0.32$ & $70.63 \pm 0.78$ \\
\hline
\end{tabular}

Table 2: Showing storage stability of cellulase enzyme of wild and mutant E-11 of Bacillus sp. HCB-21.

Enzyme from mutant when incubated at $30^{\circ} \mathrm{C}$ and $40^{\circ} \mathrm{C}$ showed better stability in comparison to the wild one.

\section{Discussion}

The results of the various experiments conducted to enhance the activity of cellulase through mutagenesis of hyper producer Bacillus sp. HCB-21 using chemical and physical mutagens and further optimization of various reaction conditions have been discussed in the following sections. Various techniques are available for strain improvements such as genetic engineering, metabolic engineering, and mutagenesis. Of these techniques, mutagenesis which has been efficiently used are one of the best economic method for improvement of microorganisms [10]. Mutants, have been successfully constructed using error PCR (ePCR) and high throughput screening system to screen the library for improved activity $[11,12]$. In the present study, Bacillus sp. HCB-21 has been used for cellulose degradation. In order to enhance its cellulolytic potential various culture conditions were optimized and M5 medium supplemented with 1.6\% CMC as inducer, $(\mathrm{pH}$ 8.0) rich in minimal salts was found best for cellulase production in $30 \mathrm{~h}$ when incubated at $30^{\circ} \mathrm{C}$ with maximum cellulolytic activity, i.e., $14.51 \pm 0.63 \mathrm{U} / \mathrm{mg}$ protein. Similar results were observed by Dias and co-workers when Bacillus sp. C1AC55.07 was grown at $32^{\circ} \mathrm{C}$ for $54 \mathrm{~h}$, produce $366 \mathrm{U} / \mathrm{L}$ cellulase activities [13]. Similar findings were also observed by Verma et al., when Bacillus subtilis was grown at $45^{\circ} \mathrm{C}$ for $48 \mathrm{~h}$ which showed $11.5 \mathrm{IU} / \mathrm{ml}$ and $12 \mathrm{IU} / \mathrm{ml} \mathrm{CMC}$ activity respectively [14].

In order to enhance the cellulolytic potential of Bacillus sp. HCB21 it was subjected to chemical, i.e., EMS, MMS, BU and physical mutagenesis using UV. Total 243 mutants were generated, out of which 19 showed higher activity than wild and rest showed activity similar or less than wild. Five mutants which showed quite higher cellulase activity were further sub-cultured till seventh subculture and the mutant strain (EMS-11) generated using $100 \mathrm{mM}$ EMS was selected for further studies based on its comparative performance. The enhancement in enzyme activity more is due to increase in gene copy number and amplification of the DNA region [15]. The EMS has been reported to induce point mutation by transition i.e. GT to AT base pair [16]. The enzyme activity largely depends on the buffer system, concentration, and $\mathrm{pH}$ of buffer component and $\mathrm{pH}$ of the reaction medium. The cellulase activity of wild and mutant of Bacillus sp. HCB-21 was found maximum at $\mathrm{pH}$ 5.0 and $\mathrm{pH} 6.0$ respectably in citrate buffer. It indicates that the enzyme had attained the most active (catalytic state) ionization state at this $\mathrm{pH}$.

The results of the present study, i.e., enzyme being most active at $\mathrm{pH} 6$ are also similar to the findings. Results showed that $\mathrm{pH}$ above and below the $\mathrm{pH}$ range of 4-9 caused the loss of activity. Variation of external $\mathrm{pH}$ may directly affect cytoplasmic $\mathrm{pH}$ of microbial cells thus resulting in decreased microbial growth or enzyme production by disrupting the plasma membrane or inhibiting the activity of different metabolic enzymes. Alteration of $\mathrm{pH}$ may also change the ionization state of nutrient molecules and reduce their availability to the organism. Change in the $\mathrm{pH}$ not only affects the shape of the active site of the enzyme but may also change the charge properties of substrates so that either the substrate cannot bind to the active site or its catalysis is not achieved. Buffer maintains an ambient $\mathrm{pH}$ and ionic strength for activity of enzyme. The enzyme assumes perfect conformation or ionization state at optimum $\mathrm{pH}$ that favors maximum catalysis [17].

The maximum activity of cellulase was observed at $1.5 \%$ concentrations of CMC for both Bacillus sp. HCB-21 (22.77 U/mg protein) and mutant EMS (74.23 U/mg protein) [18-20]. Verma et al. [14] have also reported the maximum activity of $20 \mathrm{IU} / \mathrm{ml}$ with $1.5 \%$ substrate concentration. Higher or lower substrate concentrations caused decreasing activity. Bacillus sp. HCB-21 gave maximum cellulolytic activity in 25 min whereas in case of mutant E-11 reaction time was reduced by $20 \mathrm{~min}$ thus revealing greater affinity of enzyme towards substrate compared to wild strain [21-25]. With the increase in time enzyme activity decreased which might be due to denaturation of the enzyme on prolonged incubation. The enzymes from both wild and mutant were stable up to $40^{\circ} \mathrm{C}$ and beyond this temperature activity decreased [26-28].

Higher temperature resulted in higher kinetic energy which in turn lead to fasten the rate might result in thermal denaturation of enzyme. At $40^{\circ} \mathrm{C}$ and beyond the activity of cellulase of Bacillus sp. HCB-21and its mutant decreased, which might be due to the breakdown of the intermolecular attractions between polar groups (H-bonding, dipoledipole attraction) as well as the hydrophobic forces between non-polar groups within the protein structure with temperature changes [9]. Secondary and tertiary structures of protein also change when these forces are disturbed. Some researchers have also reported maximum production of cellulase at $40-50^{\circ} \mathrm{C}$ [29-31]. To increase the enzyme yield, mutant like E-11 produced in the present study seem extremely useful which can be successfully employed as a bioresource for various important biotechnological applications such as animal feed, textiles, pharmaceutical and chemical synthesis, clarification of fruit juices, manufacturing of bread and wine and renewable energy products, such as bio-ethanol after extensive $\mathrm{R} \& \mathrm{D}$ and scale-up/demonstration efforts. 
Citation: Bhatia RK, Kumar R, Rathour RK, Kumar V, Sharma V, et al. (2017) Enhancement of Cellulose Degradation Potential of Bacillus sp. Hcb-21 through Mutagenesis. J Microb Biochem Technol 9: 257-265. doi: 10.4172/1948-5948.1000374

\section{Conclusion}

The catalytic efficiency of cellulase from Bacillus sp. HCB-21 was enhanced 10 folds by chemical mutagenesis. EMS proved to be the best mutagen with enhanced cellulolytic activity $(85.04 \pm 0.46 \mathrm{U} / \mathrm{mg}$ protein) of mutant E-11 that showed better efficiency at higher $\mathrm{pH}(6.0)$ and showed higher substrate tolerance $(1.5 \% \mathrm{CMC})$ for the production of fermentable sugar. These findings showed that chemical mutagenesis can be efficiently utilized to improve the catalytic efficiency of not only cellulase but various other industrially significant enzymes.

\section{Acknowledgement}

Authors wish to acknowledge the University Grants Commission (UGC) New Delhi, India, for financial assistance as PDF to Dr. Ravi Kant Bhatia and JRF to Nidhi Rana, Vaishali Sharma, and Ranju Rathaur from UGC, MoEF and HPU respectively. The computational facility availed at Bioinformatics Centre, HP University Shimla is also duly acknowledged.

\section{References}

1. Kaushal R, Sharma N, Tandon D (2012) Cellulase and xylanase production by co-culture of Aspergillus niger and Fusarium oxysporum utilizing forest waste. Turk J Biochem 37: 35-41.

2. Ingale S, Sanket J, Gupte A (2014) Production of bioethanol using agricultural waste: Banana pseudo stem. Braz J Microbiol 45: 885-896.

3. Klemm D, Heublein B, Fink H, Bohn A (2005) Cellulose: Fascinating biopolymer and sustainable raw material. Int Edition 44: 3358-3393.

4. Narra M, Dixit G, Divecha J, Madamwar D, Shah A (2012) Production of cellulases by Solid State Fermentation with Aspergillus terreus and enzymatic hydrolysis of mild alkali-treated rice straw. Bioresour Technol 121: 355-361.

5. Naidu A, Saranraj P (2013) Bacterial enzymes: A review. Int J Pharm Biol Arch 4: $274-287$

6. Sanchez O, Cardona C (2008) Trends in biotechnological production of fuel ethanol from different feedstocks. Bioresour Technol 99: 5270- 5295.

7. Jorgensen H, Eriksson T, Börjesson J, Tjerneld F, Olsson L (2003) Purification and characterization of five cellulases and one xylanase from Penicillium brasilianum IBT 20888. Enzyme Microbial Technol 32: 851-861.

8. Schulein M (2000) Protein engineering of cellulases. Biochem Biophys Acta 1543: 239-252.

9. Sadhu S, Maiti T (2013) Cellulase production by bacteria: A Review. Br Microbiol Res J 3: 235-258.

10. Bapiraju KSN, Sujathal P, Ellaiahand P, Ramanal T (2004) Mutation induced enhanced biosynthesis of lipase. Afr J Biotechnol 3: 618-621.

11. Cherry J, Fidants A (2003) Directed evolution of industrial enzymes: An update. Curr Opin Biotechnol 14: 438-443.

12. Lai YP, Huang J, Wang LF, Li J, Wu ZR (2004) A new approach to random mutagenesis in vitro. Biotechnol Bioeng 86: 622-627.

13. Dias PV, Ramos KO, Padilha IQ, Silva FL (2014) Optimization of cellulase production by Bacillus $\mathrm{sp}$. isolated from sugarcane cultivated soil. Chem Eng Trans 38: 277-282.
14. Verma V, Verma A, Kushwaha A (2012) Isolation of cellulase enzyme from bacteria isolated from agriculture field in district Hardoi Uttar Pradesh India. Advan Appl Sci Res 3: 171-174.

15. Dubey R, Kumar J, Agrawala D, Char T, Pusp P (2011) Isolation, production, purification, assay and characterization of fibrinolytic enzymes (Nattokinase Streptokinase and Urokinase) from bacterial sources. Afr J Biotechnol 10: 1408-1420.

16. Wong TS, Roccatano D, Zacharias M, Schwaneberg U (2006) A statistical analysis of random mutagenesis methods used for directed protein evolution. J Mol Biol 355: 858-871.

17. Singh A, Kuhad R, Ward OP (2007) Industrial application of microbial cellulases. In Lignocelluloses Biotechnology. Future Prospects 355-367.

18. Antikainen N, Martin S (2005) Altering protein specificity: Techniques and applications. Bioorg Med Chem 13: 2701-2716.

19. Ariffin H, Abdullah N, UmiKalsom MS, Shirai Y, Hassan MA (2006) Production and characterization of cellulase by Bacillus pumilus EB3. Int J Eng Technol 3: 47-53.

20. Basavaraj I, Shivasharan C, Kaliwal B (2014) Isolation and characterization of cellulase producing bacteria from soil. Int J Curr Microbiol Appl Sci 5: 59-69.

21. Elba P, Maria A (2007) Bioethanol production via enzymatic hydrolysis of cellulosic 412 biomass. Published in 'The role of agricultural biotechnologies for production of bioenergy in 413 developing countries an FAO seminar held in Rome.

22. Khambhala P, Paliwal P, Kothari V (2016) Microwave mutagenesis of Brevibacillus parabrevis for enhanced cellulase production and investigation on thermostability of this cellulase. Institute of science, Nirma University, Ahmedabad-382481, Gujarat, India.

23. Kotchoni S, Shonukan O (2002) Regulatory mutations affecting the synthesis of cellulase. World J Microbiol Biotechnol 18: 487-491.

24. Kuhad R, Gupta R, Singh A (2011) Microbial cellulases and their industria applications. Enzyme Res 1: 229-233.

25. Lynd L, Weimer P, Van Z, Pretorius I (2002) Cellulose utilization. Fundamentals and biotechnol. Am Soc microbial 6693: 506-577.

26. Mai M, Kues U, Militz H (2004) Biotechnology in the wood industry. App Microbiol Biotechnol 63:477-494.

27. Majumdar P, Chanda S (2001) Chemical profile of some lignocellulosic crop residues. Ind J Agri Biochem 14: 29-33.

28. Ramanathan G, Banupriya S, Abirami D (2010) Production and optimization of cellulase from Fusarium oxysporum. J Sci Ind Res 69: 454-459.

29. Sukumaran R, Singhania R, Pandey A (2005) Microbial cellulases production, applications and challenges. J Sci Ind Res 64: 832-844.

30. Wong TS, Zhurina D, Schwaneberg $U$ (2006) The diversity challenge in directed protein evolution. Comb Chem High Thro Screen 9: 271-288.

31. Xing-Hua L, Hua-Jun Y, Bhaskar R, Dan W, Wan-Fu Y, et al. (2009) The most stirring technology in future: Cellulase enzyme and biomass utilization. $J$ Microbiol Biotechnol 1: 229-233. 